\title{
Reexamination of plant names in the literature published during the Japanese Imperialism Period with special reference to Hwangjeong and Wiyu
}

\author{
Hyunchur SHIN* \\ Department of Life Sciences, Soonchunhyang University, Asan 31538, Korea \\ (Received 21 May 2019; Revised 24 July 2019; Accepted 11 September 2019)
}

\begin{abstract}
The plant names Hwangjeong and Wiyu were written in Chinese characters in Hyang-yak-jibseong-bang during the early Chosen dynasty. However, soon after, Hwangjeong and Wiyu were written in Korean characters as Jukdae and Dung-gul-re, respectively. However, since under the Japanese imperialist period in Korea, the taxonomic identities of these two Korean names have been incorrectly understood, with scientific names incorrectly assigned as well to these two names thus far. The results of the present study prove that Hwangjeong is Polygonatum sibiricum and that its Korean name should be Jukdae, its initial Korean name, and not Cheung-cheung-gal-go-ri-dung-gul-re, as used recently. Meanwhile, during the Japanese imperialist period, Wiyu was termed $P$. officinale or P. japonicum with the Korean name of Dung-gul-re. However, the correct scientific names were shown to be synonyms of $P$. odoratum.
\end{abstract}

Keywords: plant names, under the rule of Japanese imperialism, Hwangjeong, Wiyu, Jukdae, Dunggurae

한반도에 분포하는 식물들을 대상으로 한 식물분류학 연구는 19 세기 중반부터 시작된 서양 선교사들의 방문과 그에 따른 채집 활동, 그리고 이러한 활동 결과인 표본이 서구 학계에 소개됨에 따라 시작되었고, 그에 따라 식물 분류학은 서양 과학의 한 분야로 시작된 것으로 평가되고 있다(Chung et al., 1986). 이후 1911년부터 일제강점기가 시작되면서 일본인 학자들에 의해 본격적으로 우리나라 식물 연구가 재개되었고, 소수의 한국인 학자들이 일본인 학자들의 연구에 동참하면서 학문적 성과가 나타나기 시 작한 것으로 알려졌다(Chung et al., 1986). 그런데 이 시기 에 한글 식물명을 정리하는 과정에, 특히 『조선식물향명 집朝鮮植物鄉名集』에 나열된 식물명의 내력이 밝혀지지 않아 혼란과 오해가 발생하고 있다(Cho et al., 2018).

외국에서는 식물분류학의 시작을 인류의 탄생과 함께 인류의 생존을 위한 식물의 구분, 즉 대중분류학(folk taxonomy)을 식물분류학의 시작으로 간주하면서, 이 시기 에 사용되었던 식물의 국명과 용도, 그리고 전반적인 분 류 체계를 연구하고 있다(Jones and Luchsinger, 1987). 한 가지 실례로 기원전 그리스 철학자인 테오프라스토스 (Theophratos)가 쓴 것으로 알려진 『식물 탐구 Enquiry into Plants』와『식물의 성장 The Causes of Plants』에 있는 식물
분류학 관련 내용에서, 그가 식물을 교목, 관목, 아관목 그 리고 초본으로 분류했음도 파악했다(Radford et al., 1974). 중국에서도 중국 고전에 나오는 고대식물분류학과 그 사 상에 대한 연구가 수행되었는데, 사람들의 실제적 필요나 용도 또는 쉽게 얻을 수 있는 식물의 특징에 근거해서 진 행되었던 식물분류를 고대인위분류하고 부르면서, 고대 의학서로 알려진 『신농본초경神農本草經』에 나열된 식 물들의 분류체계가 검토되었다(Chin, 1978). 우리나라에 서도 최근 고문헌에 대한 관심이 높아지면서, 『동의보감 東醫寶鑑』을 비롯한 우리나라 옛 문헌에 나오는 식물들의 분류체계에 대한 논의는 수행된 바 있다(Kim, 2015).

그런데 우리나라에서 1820 년대에 발간된 것으로 추정 된 『물명고物名考』에는 “馬薪蒿”가 “호마와 비슷하지만 팔월에 열매가 맺고, 소두와 비슷하지만 열매가 길다(茣之 最粗者七月華似胡麻八月細角似小豆角銳而長)”라고 설명 되어 있다. 이러한 설명은 오늘날 식물분류학에서 말하는 식별형질을 나열한 것으로, 조선시대에 이미 식물의 식별 형질을 이용하여 식물을 구분했음을 의미한다. 또한 『물 명고』에는 한자로 표기된 식물명 4,278개 항목이 초부(草 部)와 목부(木部) 두 무리로 분류되어 있고, 같은 식물을 지칭하는 다른 이름들, 즉 이명들에는 같음을 의미하는

\footnotetext{
*Author for correspondence: shinhy@sch.ac.kr
} 
“소”이라는 표기가 있는데, 그 수만도 2,000여 개에 달한 다(unpublished data). 즉, 식물에 대한 설명 방식과 분류, 그 리고 한글 이명의 나열은 현대의 식물분류학 방법론과 상 당히 비슷한 것으로 평가할 수 있을 것이다. 그리고 이 시 기에 이런 성과가 도출되었다면, 이 시기 이전에도 우리 나라에서 식물분류학과 관련된 연구 성과들이 도출되었 을 것이라는 추정도 가능할 것이다. 실제로 한국 최고의 의서로 알려진 『향약집성방師藥集成方』과 『동의보감』 에는 약재로 사용되는 약재명과 약재명의 우리말 이름이 기록되어 있을 뿐만 아니라 식물의 분포와 형태적 특징 등도 기재되어 있어, 이 책들은 식물분류학이라는 관점에 서 재검토가 필요한 책들이다.

그럼에도 18 세기 이전의 연구 성과에 대한 체계적인 검 토가 진행되지 않은 상태에서 19세기, 특히 일본학자들에 의해 식물분류학 연구가 수행되었고, 그에 따라 이전에 사용되던 국명과 일제강점기에 정리된 국명이 일치하지 않은 사례들이 발견되고 있다. 실례로 『동의보감』에는 창 포와 석창포가 같은 식물을 지칭하는 이름으로 사용되었 으나, 오늘날에는 서로 다른 식물의 이름으로 사용되고 있는데, 일제 강점기에 학명과 국명을 잘못 일치시킨 결 과이며(Shin et al., 2017), 진교(秦艽)라는 식물명에는 원래 진교라고 부르던 식물과는 전혀 다른 Aconitum pseudolaeve라는 종에 학명을 일치시킨 시기도 바로 일제 강점기였던 것으로 파악되었다(Shin et al., 2017).

따라서 본 연구에서는 한국 최고의 의서로 알려진 『향 약집성방』과 『동의보감』에서 설명하는 나오는 황정(黄精) 과 위유(萎落)를 대상으로 일제강점기 이전에 간행된 우 리나라 자료들과 일제강점기에 발간된 각종 자료들을 비 교하여, 이들의 분류학적 실체를 규명함과 동시에, 일제 강점기에 발간된 식물학 관련 문헌에 나오는 국명의 문제 점들을 파악하고, 문제 해결 방안을 모색하고자 했다. 이 두 식물은 약재로 널리 사용되고 있으나, 위유를 황정으 로, 황정을 진황정으로 사용하고 있어 약물의 이름을 호 칭할 때와 약을 먹을 때에 혼란을 야기하고 있어(Ahn, 1985), 이들의 분류학적 실체 규명이 시급한 것으로 판단 되었다.

\section{재료 및 방법}

황정과 위유의 분류학적 실체를 파악하고, 이를 근거로 이들의 국명을 파악하기 위하여, 『향약집성방』과 『동의 보감』을 비롯하여 우리나라 고전에서 이들의 용례를 검색 했다. 『향약집성방』은 한국학중앙연구원에 소장된 판본 과 『국역 향약집성방』(Shin et al., 1998)을, 『동의보감』은 한국학중앙연구원에 소장된 판본과 『신편 대역 동의보 감』(Anonymous, 2006) 내용을 검토했다. 이밖에 국사편찬 위원회의 한국사데이터베이스(Database in Korean History), 한국고전번역원의 한국고전종합DB (DB of Korean Classics),
그리고 조선왕조실록(The Annals of the Joseon Dynasty) 등 에서 ‘황정'과 '위유'라는 식물명을 검색했다. 그리고 국 내에서 발간된 각종 도감류와 국명집을 비교 검토해서, 고전에 설명된 식물들의 특성에 맞는 분류학적 실체를 파 악하고, 이를 토대로 학명과 국명을 조사했다. 한편, 중국 고전에 나오는 ‘황정'과 ‘위유'는 중국의 백가제자(百家諸 子, Chinese Text Project, 2019)에서 확인했고, 중국식물지 영문판(Flora of China in English, 2019)과 중문판(Flora of China in Chinese, 2019)을 참고했다. 한편, 우리나라 고전 에 실려 있는 '황정'과 '위유'에 관련된 내용은 한의학고 전 $\mathrm{DB}$ 를 비롯하여 한국고전종합 $\mathrm{DB}$, 조선왕조실록 등이 제공하는 번역문을 인용했다.

\section{결과 및 고찰}

\section{조선 시대 문헌에 나오는 황정과 위유의 국명}

黄精(황정, Hwangjeong)이라는 한자명은 『향약집성방』 에 처음 나오는데, 향명(鄉名), 즉 우리말 이름이 竹大根으 로 표기되어 있으며, 이후 발간된 『동의보감』에는 한글 이 름이 듁댓불휘로 되어 있었다. 그리고 17 세기말에서 18 세 기 초에 편찬된 『산림경제山林經濟』에는 黃精의 한글 이 름이 듁대불휘라고 표기되어 있었다. 그런데, 1527년 최 세진이 지은 한자 학습서인 『훈몽자회訓蒙字會』 에는 한 자 竹이 한글로 “대 듁"으로 설명되어 있으며, 불휘는 뿌 리의 고어이기 때문에(Nam, 2017), 『향약집성방』에 나오 는 우리말 이름 竹大根은 죽대근으로 읽히는 한자가 아니 라 죽대의 뿌리로 읽어야하는 이두 또는 향찰 로 보인다. 그리고 1820 년대에 편찬된 것으로 알려진 유 희의 『물명고』에는 黃精의 한글명이 듁대로 제시되어 있 었다(Chung et al., 1997). 이밖에 저자와 편찬 년대가 알려 져 있지 않은 『본초정화本草精華』에는 黃精의 국명으로 듁뒷불휘가 병기되어 있었다.

한편 萎豚(위유, $\mathrm{Wiyu})$ 라는 한자명은 『향약채취월령鄕 藥採取月令』에 처음 나오는데, 豆應仇羅라는 우리말 이 름이 표기되어 있었다. 이후 발간된 『향약집성방』에는 女 萎萎落(여위위유)라는 한자명이 나오며 豆應仇羅라는 우 리말 이름이 병기되어 있었다. 豆應仇羅 역시 이두 또는 향찰로 추정되는데, 豆와 應은 합쳐서 둥이라는 음을, 仇 羅는 구라라는 음을 나타냈을 것으로 보이며, 따라서 모 應仇羅는 둥구라와 비슷하게 발음했을 것으로 추정되는 데(Son, 1996), 『산림경제』와『물명고』에는 둥구레로 표 기되어 있었다. 한편, 女萎萎落라는 이름은 女萎와 萎蓕 를 동시에 이어서 표기한 것으로 보이는데, 『물명고』에는 위유가 委萎와 委落로 표기되어 있는 반면, 『광재물보廣 才物譜』에는 萎菻新 藏菻로 표기되어 있었다(Chung et al., 1997). 이밖에『물명고』와『광재물보』에는 편정(扁精)이 위유와 같은 식물명으로 나열되어 있었으며, 특히 『물명 고』에는 편정의 한글명으로 둥구레가 표기되어 있었다 
(Chung et al., 1997). 그런데『본초강목本草綱目』에는 여위 가 아니라 위유가 맞다고(諸家誤以女萎解蔵芜车, 正誤見 蒇蓕下) 되어 있고, 『향약집성방』에 나오는 항목명 女萎 萎蓕를 위유(萎誑)로 표기하면서 여위(女萎)라는 이름도 쓴다는 주장도 있는데(Shin et al., 1998), 女萎와 萎誑, 葴蓕 모두가 같은 식물명으로 간주되고 있다(Shin, 2015).

이상을 정리하면, 조선시대에는 황정과 위유를 명확하 게 구분했으며, 황정은 죽대로, 위유는 둥굴레로 불렀던 것으로 추정된다. 그러나 때로 이 두 종을 혼동하기도 했 던 것으로 보이는데, 『향약집성방』권 지초영지의 정수다. 일명 위유라고 한다(黃精者, 是芝草 精也, 一名萎芜萑.)”라고 설명되어 있고, 작자와 편찬년도가 미상인 『광재물보』에는 黃精의 한글명이 둥구레로 되어 있었다(Chung et al., 1997).

\section{조선 시대 문헌에 나오는 황정과 위유의 분포}

황정은 『조선왕조실록朝鮮王朝實錄』「평안도本安道」 의 약재로 기록되어 있으며, 『동의보감』에는 "평안도에만 분포하며 평상시에 공물로 바친(我國惟本安道有之 本時 上貢焉)" 것으로 설명되어 있다. 그리고 『산림경제』, 1771 년 서명응이 편찬한 『고사신서放事新書』, 19세기에 이규 경이 편찬한 『오주연문장전산고五洲衍文長箋散稿』등에 도 평안도에 황정이 자라는 것으로 설명되어 있고, 1806 년에 시작하여 1841 년에 걸쳐 서유구가 편찬한 『임원경 제지林園經濟志』에는 “평안도 영변의 것이 최고이며, 충 청도 목천 등지에도 있다(以關西寧邊者爲最 今湖西木川 等地亦有之).”고 설명되어 있다.

위유는 『향약집성방』에 산골짜기나 낮은 산에서 자라 는 것으로 설명되어 있을 뿐, 특정한 지역명은 나열되어 있지 않았다. 한편 『동의보감』을 비롯하여 黃精에 대한 설 명이 나열된 『산림경제』, 『고사신서』, 『오주연문장전산 고』등에서는 위유의 분포에 대한 정보가 검색되지 않았다.

\section{조선 시대 문헌에 나오는 황정과 위유의 형태학적 특징}

『향약집성방』과『동의보감』에서 설명하는 황정의 특 징은 대부분은 중국 의약서에 있는 내용을 인용한 것인데 (Oh, 2011), 뿌리는 어린 생강과 비슷하며 황색이다(根如 嫩生薑黃色). 잎은 대나무 잎처럼 생겼으며(其葉如竹 또 는 葉如竹葉), 4장씩 마주보며 달리며(兩兩相對), 줄기는 부드럽고(菣梗柔脆) 복숭아가지처럼 생겼으며(其䔄如桃 또는 頗似桃枝), 아래쪽은 황색이나 정단은 붉은 빛이 돈 다(本黃末赤). 꽃은 4월에 청백색으로 피며(四月開細靑白 花), 팥의 꽃처럼 생겼다(如小豆花狀). 열매는 기장과 비 슷하거나(其實如㯟), 씨가 흰색으로 기장과 비슷한데(子 白如㯟) 열매에 씨가 없는 것도 있다(亦有無子者).

이밖에 『향약집성방』에는 황정과 "거의 비슷한 구문(銁 吻)을 사용해서는 안 되는데, 구문에는 모구자(毛鉤子)가 2 개 있어 황정과 구분된다(凡使勿用鈎吻, 眞似黃精, 只是
葉有毛鉤子二箇, 是別認處.)”는 설명이 있다. 또한, 『향약 집성방』과 『동의보감』의 참고문헌으로 알려진 『경사증 류비급본초經史證類備急本草』(흔히 줄여서『증류본초 證類本草』라고 부른다)에도(Oh, 2011), “잎은 곧 구문과 서 로 유사하고(其葉乃與鉤吻相似)”라는 설명이 있다. 모구 자의 정확한 실체는 알 수 없으나, 글자 그대로 해석하면 갈고리 모양으로 구부러진 잔털 구조로 추정된다.

위유에 대한 설명은 『향약집성방』에만 있고『동의보 감』에는 없다. 위유의 잎은 황정과 비슷하게 좁고 길며 위 쪽은 하얀색이고 아래쪽은 청색이며(葉狹而長, 表白裏靑, 亦類黃精.), 줄기는 대나무로 만든 화살처럼 뻣뺏하며, 마 디가 있고(茎幹強直, 似竹箭, 簳有箩.), 뿌리는 노란색으 로 수염뿌리가 많으며 크기는 손가락만하고 길이는 30 $60 \mathrm{~cm}$ 정도인(根黃多䰅大如指長一二尺) 것으로 『향약집 성방』에 설명되어 있다. 또한 위유는 마디에 털이 있고(節 上有毛), 줄기에는 반점이 있으며(茥斑), 잎 끝에는 작은 노 란색 반점이 있는(葉尖處有小黃點) 특징도 지니고 있다.

\section{일제 강점기 시대와 그 이후 문헌에 나오는 황정과 위유}

일제 강점기인 1917년 조선총독부에서 발간한 『조선한 방약료식물조사서朝鮮漢方藥料植物調査書』에는 듁네라 는 한글명이 Polygonatum officinale Allioni라는 학명에 병 기되어 있는데, 한글명의 출처에 “東醫”라고 표기되어 있 어 『동의보감』에 나오는 황정을 P. officinale로 간주한 것 으로 보인다. 동시에 P. officinale의 지하경을 황정이라고 부르며, 전국에 걸쳐 분포한다고 설명했다(Ishidoya, 1917). 그리고 1920년 조선총독부에서 발간한 『조선어사전朝鮮 語辭典』에는 죽대와 둥굴레 모두가 黃精으로 설명되어 있 다. 즉, 죽대 항목에는 “黃精(菟竹)”이라는 설명만 있으며, 둥굴네의 항목에는 “菟蔛(仙人仮, 黃精, 대뿌리)”로, 黃精 의 항목에는 “둥굴네와 같다(둥굴네に同じ)"라는 설명이 있다.

이후 1922년 Mori는 ${ }^{\circledR}$ An Enumeration of Plants Hitherto Known from Corea』에서 P. falcatum과 P. officinale의 국명 으로 黃精을 사용했으며, “쥭대”라는 이름은 P. falcatum과 P. lasianthum Maxim. var. coreanum Nakai에 나열했다(Mori, 1922 ) 이후 1934년 村田惁磨는 『토명대조만선식물자휘土 名對照滿鮮植物字彙』에서 P. japonicum C. Morren \& Decaisne에는 위유, 옥쥭, 죽네풀, 괴무릇을, P. sibiricum Redouté에는 구문(鉤吻)을, 그리고 P. verticillatum Allioni에 는 황정, 토쥭, 죽대, 선인반, 둥굴네, 대?리라는 국명을 나 열했다(Murata, 1932).

한편 우리나라 학자들도 황정과 위유의 실체를 규명했

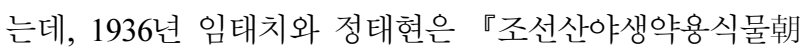
鮮産野生藥用植物』에서 황정을 P. japonicum으로 간주했 고, 국명으로 둥굴네와 괴불곳을 나열했다(Hayashi and Tei, 1936). 이후 1937년 정태현 등은 『조선식물향명집』에 서 P. japonicum에는 黃精과 둥굴레를, P. falcatum에는 댓잎 
Table 1. Korean and scientific names of Polygonatum species published since 1917.

\begin{tabular}{|c|c|c|c|c|c|c|c|}
\hline Scientific name & $\begin{array}{c}\text { Ishidoya } \\
\text { (1917) }\end{array}$ & $\begin{array}{l}\text { Mori } \\
(1922)\end{array}$ & $\begin{array}{r}\text { Murata } \\
(1932)\end{array}$ & $\begin{array}{c}\text { Chung et al. } \\
\text { (1937) }\end{array}$ & $\begin{array}{c}\text { Anoymous } \\
(1976)\end{array}$ & $\begin{array}{l}\text { Jang } \\
(2002)\end{array}$ & Remark \\
\hline P. falcatum & - & 黃精, 쥭대 & - & 댓잎둥굴레 & 대잎둥굴레 & $\begin{array}{c}\text { 진황정, } \\
\text { 댓잎둥굴레 }\end{array}$ & - \\
\hline P. sibiricum & - & - & 구문 & - & $\begin{array}{c}\text { 죽대둥굴레 } \\
\text { (낚시둥굴레) }\end{array}$ & $\begin{array}{l}\text { 층층갈고리 } \\
\text { 둥굴레 }\end{array}$ & - \\
\hline P. stenophyllum & - & - & - & - & 층층둥굴레 & $\begin{array}{l}\text { 층층둥굴레, } \\
\text { 수레둥굴레 }\end{array}$ & - \\
\hline P. verticillatum & - & - & $\begin{array}{l}\text { 황졍, 죽대, } \\
\text { 둥글네 }\end{array}$ & - & - & - & $\begin{array}{l}\text { Not distributed in } \\
\text { Korea }\end{array}$ \\
\hline P. lasianthum & - & - & - & - & - & $\begin{array}{c}\text { 죽대, } \\
\text { 큰대잎둥굴레, } \\
\text { 큰댓잎둥굴레 }\end{array}$ & - \\
\hline $\begin{array}{l}\text { P. lasianthum var. } \\
\text { coreanum }\end{array}$ & - & 죽대 & - & $\begin{array}{c}\text { 큰댓잎둥굴레 } \\
\text { (죽대) }\end{array}$ & $\begin{array}{c}\text { 큰대잎둥굴레 } \\
\text { (죽대) }\end{array}$ & - & $\equiv P$. lasianthum \\
\hline $\begin{array}{l}\text { P. odoratum var. } \\
\text { pluriflorum }\end{array}$ & - & - & - & - & $\begin{array}{c}\text { 둥글레, 괴불곳, } \\
\text { 둥굴네 }\end{array}$ & - & $\equiv$ P. odoratum \\
\hline P. officinale & $\begin{array}{l}\text { 듁네, } \\
\text { 黃精 }\end{array}$ & $\begin{array}{l}\text { 둥굴네, 괴불곳, } \\
\text { 玉竹, 萎芜任, } \\
\text { 黃精, 白披 }\end{array}$ & - & - & - & - & $\equiv P$. odoratum \\
\hline P. japonicum & - & - & $\begin{array}{l}\text { 위유, 옥쥭, } \\
\text { 죽네풀, } \\
\text { 괴무릇 }\end{array}$ & $\begin{array}{l}\text { 둥굴레, } \\
\text { 黃精 }\end{array}$ & - & - & $\equiv P$. odoratum \\
\hline
\end{tabular}

둥굴레를, P. lasianthum var. coreanum에는 큰댓잎둥굴레와 죽대라는 국명을 부여했다(Chung et al., 1937) (Table 1).

그리고 일제 강점기가 지난 1949년 정태현 등은 $P$. falcatum 에 진황정이라는 이름을 부여했고(Chung et al, 1949), 1949년 박만규는 P. odoratum var. pluriflorum (Miq.) Ohwi에 둥굴레라는 이름을 부여했다(Park, 1949). 그리고 1988년 장창기는 P. odoratum var. odoratum에 풍도둥굴레, P. sibiricum에 층층갈고리둥굴레라는 이름을 각각 부여했 다(Jang, 1998). 이밖에 생약학계에서는 황정을 P. sibiricum 으로 간주하면서 죽대둥굴레라는 이름을 부여했다(Shin et al., 1998; Shin, 2015).

\section{황정과 위유의 분류학적 실체}

우리나라 옛 문헌에 기록된 황정과 위유를 중국에서는 P. sibiricum과 P. odoratum으로 각각 간주하고 있다(Chen and Tamura 2000). 단지 영문판 중국식물지에는 $P$. odoratum 의 중국명으로 玉竹만 기재되어 있으나, 중문판 중국식물지에는 玉竹의 다른 이름으로 萎菻가 나열되어 있고(Wang et al., 1978), 중국 명나라의 이시진이 지은 의학

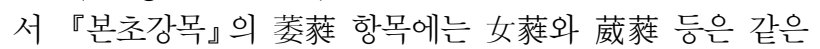
이름이라고 설명되어 있다. 또한 우리나라에서도 황정과 위유를 둥굴레속(Polygonatum) 식물로 간주하고 있어, 이 두 식물명은 둥굴레속에 속하는 식물로 추정된다.

식물명 황정의 경우, 중국에서는 P. sibiricum으로 간주
하고 있으나(Wang et al., 1978; Chen and Tamura, 2000), 우 리나라에서는 여러 분류군에 황정이라는 이름을 사용했 다. 즉, 일제 강점기에 Mori (1922)가 P. falactum을 황정으 로 부르기 시작해서, Murata (1932)는 P. verticillatum을, Hayashi and Tei (1936) 그리고 Chung et al. (1937)은 $P$. japonicum을 황정으로 불렀다. 그리고 일제 강점기를 벗어 난 이후에는 황정이라는 이름이 사용되지 않았다. 단지 Chung et al. (1949)이 P. falcatum을 진황정으로 불렀는데, 아마도 진짜 황정, 즉 眞黃精의 의미로 불렀던 것으로 보 인다. 한편 P. verticillatum은 국내에는 분포하지 않으며 (Chen and Tamura, 2000), P. japonicum은 P. odoratum 과 동 일한 종으로 간주되고 있다(Chen and Tamura, 2000). 따라 서 일제 강점기에 황정이라는 식물명은 P. falcatum과 $P$. odoratum 두 종에 사용된 것으로 보인다.

한반도에 분포하는 둥굴레속(Polygonatum) 식물들은 잎 의 배열 상태에 따라 크게 두 무리, 즉 잎이 호생하는 둥굴 레절(section Polygonatum)과 대생하는 층층둥굴레절 (section Verticillata)로 구분된다(Jang, 2002). 그리고 우리나 라 고전에 나오는 황정은 잎이 대생하는 무리로 설명되어 있기 때문에, 황정은 대생하는 무리에 속할 것이다. 그리고 대생하는 무리에는 층층둥굴레(P. stenophyllum)과 층층갈 고리둥굴레(P. sibiricum) 두 종만이 존재한다. 그리고 이 두 종은 잎 선단이 말리는 여부로 구분되는데, P. stenophyllum 은 잎 선단이 말리지 않는 반면, P. sibiricum은 잎 선단이 
말린다(Jang, 2002). 그런데 우리나라와 중국의 옛 문헌에 따르면 황정의 잎에는 갈고리처럼 생긴 구조가 있기 때문 에, 황정은 P. stenophyllum보다는 잎 선단이 말려 갈고리처 럼 보이는 P. sibiricum과 더 잘 일치하는 것으로 보인다.

단지 황정이 『동의보감』에는 평안도에만 분포하는 것 으로 되어있으나, 『임원경제지』에는 충청도 목천에도 분 포한다고 되어있다. 그런데, 오늘날 충북 단양 근처에서 $P$. sibiricum을 재배하는 것으로 보아(Jang, 2002), 『임원경제 지』의 언급은 자생하는 것이 아니라 재배하는 상황을 설 명한 것으로 추정된다. 이밖에 황정을 P. stenophyllum로 간 주하면서 충북 단양이 자생하는 남한계선이라는 주장도 제기되었으나(Choi et al., 1996), 이 지역에서 20년 이상 중 국산 재배종인 P. sibiricum을 재배해 왔기 때문에, $P$. sibiricum을 P. stenophyllum 으로 오동정한 것으로 추정된다 (see Jang, 2002).

한편, 황정의 경우 열매에 씨가 없는 것도 있다고(亦有 無子者)『동의보감』과 『향약집성방』에 설명되어 있는데, P. sibiricum 의 경우 결실률이 $36 \%$ 정도로 보고되고 있어 (Tian et al., 2009), 씨가 없는 경우를 설명해주는 것으로 보 인다. 특히 우리나라에서는 P. stenophyllum으로 오동정된 것으로 추정되는 P. sibiricum의 경우 전혀 결실하지 않는 것으로 보고되었다(Jang et al., 1998). 반면, P. stenophyllum 은 덩굴식물에 피복되면 종자가 성숙하기 전에 떨어지거 나 괴사하며(Song et al., 2009), 일부 지역에서는 열매가 성 숙하지 않은 것으로 알려졌을 뿐(Chung et al., 2014), 정확 한 결실률은 알려져 있지 않다.

위유의 분류학적 실체를 규명하는 형태학적 특징과 관 련된 자료는 부족하지만, 중국에서 위유를 P. odoratum으 로 간주한 점(Wang et al., 1978), 『향약채취월령』에 우리말 이름으로 豆應仇羅로 표기되었고 이후 한글로 둥구레라 고 불렀던 점, 萎落를 비롯하여 女豚科藏落 등이 모두 같 은 식물명인 점으로 볼 때, 우리나라 고전에 나오는 위유 역시 P. odoratum으로 추정된다. 단지 『향약집성방』에 마 디에 털이 있고 줄기에는 반점이 있으며 잎 끝에는 작은 노란색 반점이 있는 특징을 위유가 지니고 있다고 되어있 으나, 이런 특징은 P. odoratum에서 나타나지 않는다. 그러 나 잎 뒷면에 유두상 또는 조모상의 털이 때로 달리는데 (Chen and Tamura, 2000) 이 돌기들이 마디까지 이어지기 도 하여 마치 마디에 털이 있는 것처럼 보이기도 한다. 그 러나 줄기의 반점, 잎의 반점은 둥굴레에서 확인되지 않 았다.

한편, 편정이 『물명고』와『광재물보』에 위유와 같은 식 물명으로 표기되어 있다. 그러나 『증류본초』에는 위유는 “편정과 매우 유사하다(極似偏精)”로 설명되어 있고, 『본 초강목』에도 같은 설명이 반복되어 있고, 또한 『동의보 감』에는 “잎이 둘러난 것이 황정이고, 어긋난 것이 편정( 其葉相對爲黃精, 不對爲偏精.)”으로 설명되어 있어, 편정 과 위유는 다른 식물로 추정된다. 단지 본 연구에서는 편
정의 분류학적 실체를 파악하지 않았는데, 추후 규명되어 야 할 것으로 사료된다.

\section{황정과 위유의 한글 이름}

우리나라 옛 문헌에 기록된 황정을 P. sibiricum으로 간 주할 경우, 황정과 관련된 우리말 이름으로는 『향약집성 방』에 표기된 黃精의 향명인 竹大根, 『동의보감』에 표기 된 향명 듁댓불휘, 일제 강점기에 사용되었던 구문 (Murata, 1932), 북한에서 사용한 죽대둥글레와 낚시둥굴 레(Anonymous, 1976), 그리고 가장 최근에 사용된 층층갈 고리둥굴레(Jang, 1998)와 죽대둥글레(Shin et al., 1998; Shin, 2015)가 있다.

이 중 竹大根의 경우, 竹大의 뿌리(根)라는 의미로 사용 된 이름으로 보이며, 竹大는 한자가 아니라 우리말을 한 자를 빌려 표기한 이두나 향찰로 추정되는데, 『향약집성 방』이 1446년 훈민정음이 반포되기 전인 1423년에 편찬 되어 한글로 표기할 수 없었기 때문이다. 이런 점은 훈민 정음 반포이후 편찬된 『동의보감』과 『산림경제』, 『물명 고』등에는 竹大로 표기되지 않고 듁대로 표기된 점으로 뒷받침된다. 그런데 竹大는 오늘날 표기에 따르면 듁대가 아니라 죽대이며, 따라서 황정의 우리말 이름은 맨 처음 죽대로 기록된 것으로 간주해야만 할 것이다.

그럼에도 불구하고, Ishidoya (1917)는 듁네라는 이름에 P. sibiricum 대신 P. officinale라는 학명을 일치시켰고, 이후 Mori (1922)도 황정 또는 죽대에 P. falcatum과 P. lasianthum var. coreanum이라는 전혀 다른 종의 학명을 부여했다. 그 러나 이 두 종은 모두 잎이 호생하는 무리로 황정과는 전혀 다른 식물이다(Jang, 2002). 그리고 Murata (1932)는 국내에 는 분포하지 않은 銁吻이라는 한자명과 구문이라는 한글 명과 함께 P. sibiricum에 부여했으나, 이 식물명은 국내에 는 분포하지 않은 Gelsemium elegans (Gardner \& Champion) Bentham을 지칭한다(Li and Leeuwenberg, 1996). 두 사람 모 두 황정의 실체를 정확하게 파악하지 못한 것이다.

이후 임태치와 정태현 역시 황정을 둥굴레, 즉 $P$. japonicum ( $\equiv P$. odoratum)으로 간주했고(Hayashi and Tei, 1936), 정태현 등도 황정과는 전혀 다른 P. lasianthum var. coreanum에 큰댓잎둥굴레와 죽대라는 이름을 부여했고 (Chung et al., 1937), 북한에서도 비슷하게 처리했다 (Anonymous, 1976; Im, 2000). 그리고 P. lasianthum var. coreanum 이 P. lasianthum과 구분되지 않는 것으로 간주됨 에 따라 P. lasianthum에 죽대라는 이름이 부여되었다(Jang, 2002).

죽대와 황정은 『향약집성방』을 비롯하여 『동의보감』에 도 같은 식물을 지칭하는 이름으로 사용되었음에도 불구 하고, 오늘날에는 전혀 다른 두 식물을 지칭하는 이름으 로 사용되고 있으며(see Lee, 1996), 그에 따라 “竹大를 황 정의 대용 향약으로 사용"해 왔다는 주장도 제기되었다 (Lee, 2002). Ishidoya (1917)와 Mori (1922)에서 시작된 오류 
가 교정되지 않고 지속되다가 한자식물명 황정의 순우리 말 이름이었던 죽대가 전혀 다른 식물의 한자식물명으로 전환되어 버린 결과를 초래한 것이다. 그리고 이러한 혼 란을 피하려고 죽대둥굴레라는 이름도 새롭게 만들어진 것으로 추정되는데, 이 이름은 전혀 다른 두 종류의 식물 이름, 즉 죽대와 둥굴레를 하나로 만든 것으로 또 다른 혼 란을 야기할 수 있을 것으로 보인다.

위유는 『향약채취월령』에 豆應仇羅로 표기된 이후, 둥 구레를 거쳐 오늘날에는 둥굴레로 부르고 있다(Lee, 1996). 단지 『조선어사전』에는 대뿌리가 추가되었고, Mori (1922)는 괴불곳, Murata (1932)는 옥쥭, 죽네풀이라 는 이름을 위유와 같은 이름으로 기록했다. 위유의 한글 이름으로 맨 처음 사용했던 둥굴레가 타당할 것이다.

\section{우리나라 식물명의 근원을 찾기 위한 제언}

오늘날 통용되는 식물명은 이 땅에서 사람들이 식물을 인식하면서부터 부르기 시작했을 것이다. 신라 시대에 쓰 인 것으로 추정되는 목간에 천웅(天雄)과 와(萵), 그리고 복작(卜芶) 등의 약물 관련 내용이 있으며(Shin, 2014), 『삼국유사』에 나오는 艾와 蒜이라는 식물명이 이를 반 증하는 것으로 보인다. 그러나 신라, 고구려, 백제 삼국 시 대 등 고려 시대 이전에 식물명이 포함되었을 것으로 보 이는 한의학서는 대부분 소실되고 극히 일부가 중국이나 일본의 옛 의약서에 전해지고 있을 뿐이다(Shin, 1995).

그럼에도 고려 시대에 편찬된 것으로 알려진 『향약구 급방鄉藥救急方』에는 한약재명과 함께 우리말 이름이 이 두나 향찰로 기록되어 있다. 예를 들면 식물명 馬齒莧은 오늘날 쇠비름(Portulaca oleracea L.)으로 간주되는데 (Dequaan and Gilbert, 2003), 『향약구급방』에는 우리말 이 름으로 金非夌音과 金非音(Sheen, 1994), 『향약집성방』에 는 金非兽이 나열되어 있다. 金非畐을 한글로 표기하면 쇠비름이 되며, 金非陵音에서 陵音은 虞으로 대체된 것으 로 풀이되고 있다(Kim, 1983). 그럼에도 불구하고 "쇠'가 붙 어있는 식물명의 기원을 설명하면서 “쇠비름(스베리휴)" 라고 표기하여(Lee, 2016), 쇠비름이라는 이름이 마치 일 본어 스베리휴, 즉 スベリ 그에서 온 것처럼 설명하고 있어, 우리나라 식물명의 기원을 파악하는 데 혼란을 야 기할 수도 있는 상황이 벌어지고 있다.

이러한 혼란은 일제 강점기 이전의 한자 문화에서 일제 강점기를 거치면서 일어 문화로 변화되었고, 다시 일제 강 점기가 끝나면서 영어 문화로 급격하게 변화하는 과정에 우리의 옛 문헌에 대한 고증이 부족했기 때문으로 풀이된 다. 단지, 일제 강점기에 수행된 정태현과 도봉섭을 비롯한 박물학 관련 교사들에 의한 식물분류학, 특히 국명 부여와 관련된 연구, 즉 『조선식물향명집』발간은 “근대 식물학 의 보편어인 라틴어로 연구된 조선 식물에, 향명, 즉 한글 이름을 부여하여 조선의 전통 지식과 근대 식물학의 연결 고리를 되살리는 작업”(Lee, 2012)으로 평가되고 있다.
아마도 『조선식물향명집』에『향약채취월령』, 『향약본 초』, 『동의보감』, 『산림경제』, 『제중신편』, 『방약합편』 등의 고전이 인용되었기 때문에, 조선의 전통 지식과 근 대 식물학을 연결했다는 평가한 것으로 추정된다. 그러나 이들은 식물명과 관련된 너무나 많은 자료들을 정리하면 서 자신들이 참조했던 전통 지식의 근원, 즉 국명이나 분 포 또는 형태적 특징 등과 관련된 자료를 완벽하게 파악하 지 못하고, 일정 부분 혼란을 초래했던 것으로 추정된다.

우리나라에서 사용한 식물명의 근원을 찾기 위해서는 그 무엇보다도 『향약구급방』을 비롯하여 『향약집성방』, 『동의보감』, 『물명고』등 조선시대 이전에 편찬된 옛 문 헌에 실려 있는 정보들을 수집해야 하며, 이러한 정보들 을 토대로 일제 강점기에 시도되었던 식물명의 분류학적 실체 규명, 즉 현대적 의미의 식물분류학 연구가 수행되 어야만 할 것이다. 1800 년대 유희가 편찬한 『물명고』에만 도 한글 식물명이 800 여 개 정도가 수록되어 있는데, 옛 문 헌에 나오는 식물명에 대한 검토가 시급히 이루어져야만 할 것이다.

ORCID: Hyunchur SHIN https://orcid.org/0000-0001-9177-9790

\section{Acknowledgments}

This paper was supported by the Soonchunhyang University.

\section{Conflict of Interest}

The author declares that there are no conflicts of interest.

\section{Literature Cited}

Ahn, D. K. 1985. A herbal study on Polygonatum species. Korean Journal of Pharmacognosy 16: 105-113. (in Korean)

Anonymous. 1976. Flora Coreana, Vol. 7. The Science and Technology Publishing House, Pyongyang, 367 pp. (in Korean)

Anonymous, 2006. New Translation of Dongui Bogam (Principles and Practice of Eastern Medicine) Tangaekpyeon (Remedies). Buminmunhwasa, Seoul, 3987 pp. (in Korean)

Chen, X. and N. N. Tamura. 2000. Polygonatum Miller. In Flora of China, Vol. 24. Flagellariaceae through Marantaceae. Wu, Z. Y. and P. H. Raven (eds.), Science Press, Beijing and Missouri Botanical Garden, St. Louis, MO. Pp. 223-232.

Chin, C.-J. 1978. A preliminary study of the thoughts of plant classification in ancient China. Journal of Systematics and Evolution 16: 101-112. (in Chinese)

Chinese Text Project. 2019. Retrieved April 20, 2019, available from https://ctext.org.

Cho, M., W. Lee and S. Choi. 2018. The origin of Korean plant 
common names, seen through an examination of the "Determination Principles" of Joseon singmul hyangmeyongjip. Journal of the Korean History of Science Society 40: 551-608. (in Korean)

Choi, I.-S., I.-G. Song, H.-D. Lee, J.-T. Cho, K.-S. Choi, S.-S. Lee, S.-D. Kim, S.-G. Park and I.-M. Chung. 1996. Effect of seed tuber weight on growth and yield in Polygonatum stenophyllum Max. Korean Journal of Plant Research 9: 23-30. (in Korean)

Chung, M. Y., J. López-Pujol, J. M. Chung, K.-J. Kim and M. G. Chung. 2014. Contrasting levels of clonal and within-population genetic diversity between the 2 ecologically different herbs Polygonatum stenophyllum and Polygonatum inflatum (Liliaceae). Journal of Heredity 105: 690-701.

Chung, T. H., B. S. Do, D. B. Lee and H. J. Lee. 1937. Botanical Names of Joseon. Society of History of Joseon, Seoul, 222 pp. (in Korean)

Chung, T. H., B. S. Do and H. J. Shim. 1949. Plant Names in Korea, I. Herba. Society of Biology of Joseon, Seoul. 235 pp. (in Korean)

Chung, Y. H., H.-K. Choi, B.-Y. Sun, Y. C. Chung and K.-J. Kim. 1986. The history of vascular plants in Korea. In Introduction to the Historical Study of Korea Plant Taxonomy. Chung, Y. H. (ed.), Academy Publishing Co., Seoul, Pp. 1-190. (in Korean)

Chung, Y. W., Y. P. Hong, K. H. Shim and K. K. Kim. 1997. Dictionary of Chinese Terms in Later Chosen Dynasty. The Academy of Korean Studies, Seongnam, 694 pp. (in Korean)

Dequaan, L. and M. G. Gilbert. 2003. Portulaceae. In Flora of China, Vol. 5. Ulmaceae through Basellaceae. Science Press, Beijing and Missouri Botanical Garden Press, St. Louis, MO. Pp. 442-444.

Flora of China in Chinese. 2019. Retrieved April 20, 2019, available from http://frps.iplant.cn/.

Flora of China in English. 2019. Retrieved April 20, 2019, available from http://www.efloras.org/.

Hayashi, Y. and D. G. Tei. 1936. Wild Medicinal Plants of Chosen (Korea). Bulletin of Forest Experiment Station 22: 1-228. (in Japanese)

Im, R. J. 2000. Flora Koreana, Vol. 9. The Science and Technology Publishing House, Pyongyang, 378pp. (in Korean).

Ishidoya, T. 1917. Report on the Oriental Medicinal Plants in Korea. The Government of Chosen, Seoul, $60 \mathrm{pp}$.

Jang, C. G. 1998. A systematic study of the genus Polygonatum (Liliaceae) with a special reference to Korean species. $\mathrm{PhD}$ dissertation, Korea University, Seoul, 458 pp. (in Korean)

Jang, C. G. 2002. A taxonomic review of Korean Polygonatum (Ruscaceae). Korean Journal of Plant Taxonomy 32: 417-447. (in Korean)

Jang, K. H., J. M. Park, J. H. Kang and S. T. Lee. 1998. Growth and flowering characteristics of Polygonatum spp. Korean Journal of Medicinal Crop Science 6: 142-148. (in Korean)

Jones, S. B. Jr. and A. E. Luchsinger. 1987. Plant Systematics. 2nd ed. McGraw-Hill Book Company, New York, 512 pp.

Kim, D.-C. 1983. A diachronic study on the name transcription system, with special reference to Hyangmyong in the Hyangyak Chipsong-pang. MS thesis, Dankuk Univeristy, Seoul, 191 pp. (in Korean)

Kim, I. K. 2015. A study of traditional organism classification and its literature materials. Korean Studies Quarterly 38: 116-161. (in Korean)

Lee, G. W. 2002. A study on the classification of oriental herbs in Decortion Part in Dong-Eui-Bo-Gam. MS thesis, Korea National University of Education, Cheonju, 80 pp. (in Korean)

Lee, J. 2012. Contested botanizing in colonial Korea (1910-1945), conflicting visions of modernity emerging through colonial interactions between Korean and Japanese researchers. PhD dissertation, Seoul National University, Seoul, 289 pp. (in Korean)

Lee, W. T. 1996. Lineamenta Florae Koreae. Academic Books, Seoul, 1688 pp. (in Korean)

Lee, Y. O. 2016. Herb Names Rechristening by Japanese. Inmul and Sasang Publishing, Co., Seoul, 204 pp. (in Korean)

Li, P.-T. and A. J. M. Leeuwenberg. 1996. Gelsemium Jussieu. In Flora of China, Vol. 15. Myrsinaceae through Loganiaceae. Wu, Z. Y. and P. H. Raven (eds.), Science Press, Beijing and Missouri Botanical Garden Press, St. Louis, MO. P. 329.

Mori, T. 1922. An Enumeration of Plants hitherto Known form Corea. The Government of Chosen, Seoul, 624 pp.

Murata, S. 1932. Botanical Dictionary of Korean and Manchuria. Mesirokaku Showing, Tokyo, 778 pp. (in Japanese)

Nam, K. W. 2017. Kyohak Dictionary of Ancient Hangeul. Kyohaksa, Seoul, 1475 pp. (in Korean)

Oh, C.-K. 2011. Applications of Classified Emergency Materia Medica on treasured mirror of Eastern medicine and compendium of prescriptions from the countryside. Journal of Oriental Medical Classics 24: 107-118. (in Korean)

Park, M.K. 1949. An Enumeration of Korean Plants. Ministry of Education, Seoul, pp.340+176pp, (in Korean).

Radford, A. E., W. C. Dickison, J. R. Massey and C. R. Bell. 1974. Vascular Plant Systematics. Harper \& Row Publishers, New York, $891 \mathrm{pp}$.

Sheen, Y. I. 1994. A research of Hyang-Yack-Ku-Keup-Pang (Restoration and Medico-Historic Investigation). PhD dissertation, Kyung Hee University, Seoul, 190 pp. (in Korean)

Shin, D. W. 2014. History of Medicine in Chosen. Deunyuk, 
Seoul, 951 pp. (in Korean)

Shin, H., M. Nomura, I. K. Kim and S.-J. Hong. 2017. Reexamination of the Korean plant names Changpo and Sukchangpo. Korean Journal of Plant Taxonomy 47: 154-160. (in Korean) Shin, H., M. Nomura, I. K. Kim, H.-C. Ki and S.-J. Hong. 2017. Reexamination of plant names, Jingyo. Korean Journal of Plant Taxonomy 47: 328-335. (in Korean)

Shin, M. K. 2015. Clinical Traditional Herbalogy. Youngrimsa, Seoul, 956 pp. (in Korean)

Shin, M. K., K. Park and W. J. Maeng. 1998. Korean Translation Edition of Hyangyak jipseongbang $<$ III $>$ (translantion). Youngrimsa, Seoul, 2086 pp. (in Korean)

Shin, S. S. 1995. A study on the Korean traditional medical literatures before Koryo Dynasty. Korean Journal of Medical His- tory 4: 45-66. (in Korean)

Son, B.T. 1996. Research on the plants names of Hyangyak. Yeungnam Emunhak 30: 105-191. (in Korean).

Song, J.-M., G.-Y. Lee and J.-S. Yi. 2009. Growth environment and vegetation structure of natural habitat of Polygonatum stenophyllum Maxim. Journal of Forest Science 25: 187-194. (in Korean)

Tian, Q.-J., Z. Zhao and F.-G. Gu. 2009. Studies on properties of flowering and seed setting of culture Polygonatum. Seed 2009: 29-31. (in Chinese)

Wang, F. T., T. Tang, S.-C. Chen, G.-Y, Chang, L.-K. Dai, S.-Y. Liang, Y.-C. Tang, L. Liou and K.-Y. Lang. 1978. Flora Reipublicae Popularis Sinicae. Tomus 15. Science Press, Beijing, 280 pp. (in Chinese)

\title{
일제 강점기 문헌에 나오는 식물명의 재검토: 황정(黃精)과 위유(萎誑)를 중심으로
}

\begin{abstract}
신현철*
순천향대학교 생명시스템학과

적 요: 한자로 표기된 식물명 황정과 위유는 조선시대에 편찬된 『향약집성방」에 처음 나오는데, 이후 조선 시대에는 이들을 한글명으로 죽대와 둥굴레로 각각 불러 왔다. 그러나 일제강점기에 발간된 문헌에는 한글 명 죽대, 한자명 황정에 이들의 분류학적 실체와는 무관한 학명들과 한글명이 부여되어 있었으나, 이러한 오 류가 수정되지 않고 오늘날까지 이르렀다. 본 연구 결과, 한자명 황정, 한글명 죽대의 분류학적 실체는 Polygonatum sibiricum으로 확인되었고, 그에 따라 현재 사용하고 있는 한글명 층층갈고리둥굴레보다는 죽대 로 사용하는 것이 타당함이 밝혀졌다. 한편, 한자명 위유와 한글명 둥굴레는 P. odoratum으로 파악되었는데, 일제 강점기에는 이 학명의 이명으로 간주되는 학명들이 한자명 위유와 한글명 둥굴레에 부여되었음이 확인 되었다.
\end{abstract}

주요어: 한글 식물명, 일제 강점기, 황정, 위유, 죽대, 둥굴레 